\title{
The Effect of Guided Inquiry Models With Student Journals on Student Critical Thinking Skills in Environmental Change Subject
}

\author{
Reginaldis Isabella Sado ${ }^{1}$, Tien Aminatum² \\ \{isabellareginaldis@gmail.com ${ }^{1}$,tien_aminatun@uny.ac.id² \\ ${ }^{1,2}$ Graduate School of Universitas Negeri Yogyakarta, Jl. Coombo No. 1 Yogyakarta, Indonesia 5528
}

\begin{abstract}
This study aimed to determine the effect of guided inquiry models with student journals on critical thinking skills in environmental change subject. This study was a quasi-experimental research using cluster random sampling. The population of this study was all students of X Science Class of SMA Negeri 2 Ngaglik. The sample of this study was 2 namely 31 students from X Science Class as the control class and 31 students from $\mathrm{X}$ Science 3 class as the experimental class applying the guided inquiry model with student journals. Data collection was performed using a test instrument. The data obtained were analyzed using the Independent sample test of the T-test. The calculation results showed a significant value of $0.000<0.05$, so it can be concluded that there are differences in critical thinking skills between the control class and the experimental class.
\end{abstract}

Keywords: guided inquiry with student journals, critical thinking, environmental change

\section{Introduction}

The education world is one of the various fields required to undergo change in the 21 st century. This is because the education sector plays a role in producing human resources involved in the development of the 21 st century. Therefore, schools as one of the institutions in the education field must hold a curriculum based on the demands of the 21 st century development. One of the aspects developed in educational institutions is the aspect of skills. Skills needed in the face of 21st century development are critical thinking skills and problem solving skills (Özyurt, 2015) ${ }^{[19]}$. This is supported by the opinion of Liliasari (2009) ${ }^{[15]}$ stating that in the demands of an increasingly advanced and complex era of globalization, the process of science education must prepare qualified students, such as students who own scientific literacy, and have values, attitudes, and higher order thinking skills so that human resources that can think critically, creatively, be able to make decisions, and be able to solve problems will appear.

The importance of the ability to think critically as capital to deal with the demands of the times has apparently not been well implemented by educational institutions in Indonesia (Mundilarto, 2012 ${ }^{[17]}$. Based on preliminary studies conducted by Rosyid, Jatmiko \& Supardi $(2018)^{[12]}$, secondary school students' thinking skills are still low owing to the fact that the learning process is still one-way or there is only a transfer of knowledge from teacher to student so that students have difficulty building their own knowledge.

Biology is a subject included in the science family. Science is a subject of nature that can help individuals survive in an ever-changing scientific and technological world (Shishigu, Hailu dan Anibo (2018) ${ }^{[20]}$. As a subject being taught, biology has a variety of materials 
expected to be understood by students, one of which is the subject of environmental change which is very closely related to daily life. It is expected that this subject can be understood by students. However, frequently, students do not understand this subject and even just learn about existing theories. Environmental change subject should be the one that trains students' ability to think critically, because it is related to environmental problems.

The challenge is indeed for educators to design new learning and curricula that really encourage motivation and independence so as to equip students with learning and thinking

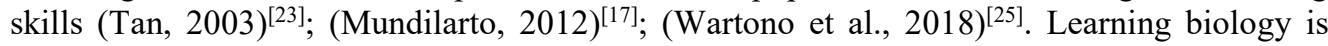
very closely related to the investigation, so it should be in the learning process that the teacher conducts practicum activities to prove the existing theories. Students can learn not only scientific concepts, but also scientific thinking skills and experimental skills. Based on the above explanation, (Nariman \& Chrispeels, 2015) ${ }^{[18]}$ in their study said that the learning process designed by the teacher must focus on students. In the student-centered learning model, the learning activities are related to inquiry activities and are based on students' reallife problems. Being able to improve critical thinking skills is a guided inquiry inquiry model (Simanjuntak, Elvis Napitupulu, Manullang, Manalu, \& Sinambela, 2019) ${ }^{[22]}$; (Kitot, Ahmad, \& Seman, 2010) $)^{[13]}$; (Hein, 2012) ${ }^{[9]}$.

Guided inquiry model of learning is included in constructivist learning (Chase, Pakhira, \& Stains, 2013) ${ }^{[3]}$; (Hein, 2012) ${ }^{[9]}$; (Conway, 2014) ${ }^{[4]}$. Constructivist learning basically states that knowledge cannot be transferred from one person to another (Hmelo-Silver, Duncan, \& Chinn, 2007) $)^{[10]}$; knowledge must be actively built by students through interaction with the environment (Domin, 1999) ${ }^{[5]}$. Inquiry-based activities are inductive, have unspecified results, and require students to make their own procedures (MacKay \& Wetzel, 2014) ${ }^{[16]}$; (Douglas \& Chiu, 2012 $)^{[6]}$. There are 6 syntaxes or steps in the guided inquiry inquiry model used in this study, namely directing students to engage in learning, displaying problems or questions, formulating hypotheses, collecting data, making conclusions, and reflecting (Arends, 2011) ${ }^{[1]}$. The study conducted by (Koksal \& Berberoglu, 2014 ${ }^{[14]}$, shows that students in the experimental class taught using guided-inquiry learning models have a positive impact on cognitive and affective characteristics. Similar findings stated (Kitot et al., 2010) ${ }^{[13]}$ that guided inquiry inquiry model is effective in improving students' academic abilities, which are critical thinking skills so it must be applied in school.

This study also uses student journals in the learning process. The use of student journals is expected to help students learn independently in order to obtain optimal results through the difficulties and allow improvements that need to be made by the teacher. According to Silbermen (2013) $)^{[22]}$ a journal is a reflective note that students make on their own every day. Student journals are expected to help students practice connecting and associating problems with the knowledge they have and can think critically and be able to relate to everyday life.

The effectiveness of guided inquiry learning models with student journals in improving students' critical thinking skills needs to be reviewed and tested empirically for further consistency in improving the ability to think critically of biology in high school students in Indonesia. This study is very important to develop learning models and theories that are able to answer the challenges and skills needs of this century.

\section{Methods}

\subsection{Research Design}

This study was a quasi-experiment. This study was conducted at the SMA Negeri 2 Ngaglik in Yogyakarta in April 2019. The population of the study was all 126 grade X 
students. The research sample consisted of one experimental class totaling 31 students and one control class totaling 31 students. The sampling was done randomly.

\subsection{Data and Analysis}

Data collection techniques used were in the form of description as the test instrument. The test instrument used was validated by the validator lecturer. In the control class and experimental class, the test before and after the learning process was done. The research

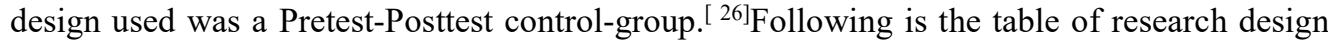
used:

Table 1. Pretest-Posttest Control-Group Research Design

\begin{tabular}{llll}
\hline Class & Pretest & Treatment & Posttest \\
\hline Control & $\mathrm{Y}_{1}$ & $\mathrm{X}_{1}$ & $\mathrm{Y}_{2}$ \\
Experiment & $\mathrm{Y}_{1}$ & $\mathrm{X}_{2}$ & $\mathrm{Y}_{2}$ \\
\hline
\end{tabular}

Remarks:

$\mathrm{Y}_{1}:$ Pretest

$\mathrm{Y}_{2}:$ Posttest

$\mathrm{X} 1$ : using the guided inquiry model with student journals

$\mathrm{X} 2$ : using scientific approach

${ }^{[8]}$ To find out the increase in students' critical thinking skills, a normalized gain score calculation using the formula is performed:

$$
\text { Gain score }(g)=\frac{\text { postest score }- \text { pretest score }}{\text { maximum score }- \text { pretest score }}
$$

In addition to the Gain score test, to find out whether there are differences in critical thinking skills in the control class and the experimental class, the research data were analyzed using an independent sample t-test with the help of the SPSS program.

\section{Result}

The results were obtained using descriptive pretest and posttest analysis to determine the critical thinking skills of the experimental class and control class students. The results of the measurement of critical thinking skills are presented in the table below:

Table 2. Data of Critical Thinking Ability Results in Experiment and Control Class

\begin{tabular}{l|l|l|l|l}
\hline \multirow{2}{*}{ Description of Mean } & \multicolumn{3}{c}{ Value of Measurement Applying Concepts } \\
\cline { 2 - 5 } & \multicolumn{2}{|c}{ Experimental Class } & \multicolumn{2}{c}{ Control Class } \\
\cline { 2 - 5 } & \multicolumn{1}{|c|}{ Pretest } & \multicolumn{1}{c}{ Postest } & \multicolumn{1}{c}{ Pretest } & \multicolumn{1}{c}{ Postest } \\
\hline Mean & 63.84 & 92.20 & 65.01 & 81.05 \\
\hline Number of Students (N) & 31 & 31 & 31 & 31 \\
\hline Standard deviation & 6.657 & 5.130 & 7.114 & 6.069 \\
\hline Maximum Value & 75 & 100 & 79 & 96 \\
\hline Minimum Value & 50 & 83 & 50 & 71 \\
\hline
\end{tabular}


Based on the data from the description it can be seen that there is an increase in critical thinking skills in both classes. Next is the presentation of the diagram of mean regarding the analysis results of the pretest and posttest values of students' critical thinking skills in the figure below:

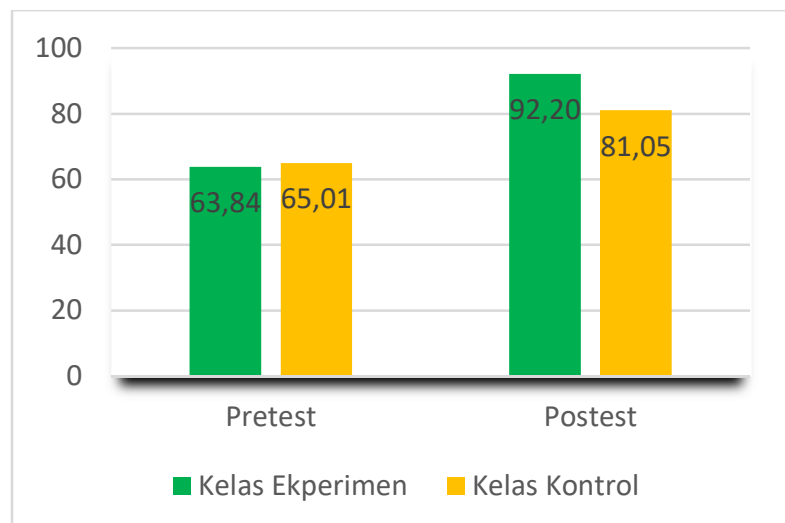

Figure 1. The mean value of students' critical thinking skills measurement

\subsection{Testing Prerequisite Analysis}

The prerequisite test is carried out to find out whether the data obtained is normally distributed and homogeneous or not. The data used were pretest and postest value data for the experimental and control classes. The first prerequisite test is the normality test, and the data can be said to be normally distributed if the sig value $>0.05$ and vice versa, if the sig value $<$ 0.05 then the data are not normally distributed. From the normality test with the SPSS program, the results are presented in the table below:

Table 3. Results of normality test for critical thinking

\begin{tabular}{l|l|l|l}
\hline No & \multicolumn{1}{|c|}{ Data } & Sig. & \multicolumn{1}{c}{ Remarks } \\
\hline 1 & $\begin{array}{l}\text { Critical thinking pretest of experimental } \\
\text { class }\end{array}$ & 0.111 & Significance $>0.05=$ normal \\
\hline 2 & $\begin{array}{l}\text { Critical thinking posttest of } \\
\text { experimental class }\end{array}$ & 0.066 & Significance $>0.05=$ normal \\
\hline 3 & Critical thinking pretest of control class & 0.127 & Significance $>0.05=$ normal \\
\hline 4 & Critical thinking posttest of control class & 0.155 & Significance $>0.05=$ normal \\
\hline
\end{tabular}

Based on the results of the normality test, it can be seen that the distribution of critical thinking skills of students is normally distributed because it has a significance value greater than 0.05 so that it can be analyzed further. The second test was the homogeneity test using pretest and posttest data of the two classes as well. Homogeneity test is performed to determine the similarity of the two variances, the data is said to be homogeneous if the sig value $>0.05$ and if the sig value $<0.05$ then the data are not homogeneous. Following is the presentation of homogeneity test results using the SPSS program:

Table 4. Data on homogeneity test of critical thinking

\begin{tabular}{l|l|l|l}
\hline Data & Levene statistic & Sig. & Remarks \\
\hline
\end{tabular}




\begin{tabular}{l|l|l|l}
\hline Pretest & .102 & 0.751 & Homogeneous \\
\hline Posttest & .830 & 0.366 & Homogeneous \\
\hline
\end{tabular}

Based on the homogeneity test results in the above table, the pretest and posttest values in both classes are greater than the significance value of homogeneity, so the experimental class and control class data values have the same variance (homogeneous).

\subsection{Hypothesis testing}

Hypothesis testing is conducted to determine whether the application of guided inquiry with student journals increases the critical thinking skills of students of X Science class in SMA Negeri 2 Ngaglik on the subject of environmental change. Data analysis used independent sample t-test in the SPSS program. The hypothesis in this study is:

Ho : there is no difference in critical thinking skills of experimental class and the control class

$\mathrm{Ha}$ : there is difference in critical thinking skills of experimental class and the control class

The Ha criterion is accepted if the sig value $<0.05$, which means there is a difference between the experimental class and the control class. The following is the presentation of the t-test results in critical thinking skills of experimental and control class students:

Table 5. t-test results in critical thinking

\begin{tabular}{l|l|c|l|l}
\hline Type of Data & Sig.(2-tailed) & A & Decision & Remarks \\
\hline Postest & .000 & 0.05 & $\begin{array}{l}\text { Ha is } \\
\text { accepted }\end{array}$ & $\begin{array}{l}\text { Significant } \\
\text { difference }\end{array}$ \\
\hline
\end{tabular}

Based on the results of the t-test in the above table, it can be seen that the significance value (2-tailed) of $0,000<0.05$ so that it is concluded that Ho is rejected and $\mathrm{Ha}$ is accepted. This means that there is a significant difference between the results of the critical thinking skills scores in the experimental class that applies guided inquiry model with student journals in the learning process and in control class that does not apply guided inquiry model with student journals. Therefore, the results of this t-test indicate that the application of guided inquiry models with student journals affected the critical thinking skills of students of $\mathrm{X}$ Science Class in SMA Negeri 2 Ngaglik on environmental change subject.

\section{$3.3 \quad$ N-Gain Test}

Increased students' critical thinking skills in the control and experimental class were obtained by calculating the pre-test and post-test scores using the N-Gain test with the help of an excel program. From the N-Gain analysis, it will be known how much the increase in students' critical thinking skills before and after treatment. Following are the results of the NGain calculation presented as presented in table 6:

Table 6. Data on N-gain test results of critical thinking skills

\begin{tabular}{l|l|l|l|l}
\hline & Mean value & & & \\
\hline
\end{tabular}




\begin{tabular}{l|c|c|c|c|c}
\hline \multicolumn{1}{c|}{ Class } & Pretest & Posttest & Increase & Gain score & Category \\
\hline Experimental & 63.8 & 92.2 & 28.4 & 0.77 & High \\
\hline Control & 65.1 & 81.0 & 15.9 & 0.44 & Moderate \\
\hline
\end{tabular}

From the table above it can be seen that the difference in the mean of increase in students' critical thinking skills in the experimental class was 28.4 and the $\mathrm{N}$-Gain value was 0.77 , while that in the control class was 15.9 and the N-Gain value was 0.44 . From these results an increase in the critical thinking skills in the experimental class was categorized high, while the category of that in control class was moderate. From the results of the N_Gain test with the help of the excel program it can be seen that the increase in the critical thinking skills of the experimental class students is higher than the control class.

\subsection{Student Journals}

In this study, student journals are assessed based on students' ability to write learning reflections after students have done the guided inquiry model. The following is the recapitulation of student journal scores:

Table 7. Recapitulation of student journal scores

\begin{tabular}{l|l|l|l}
\hline Student Journal Criteria & Score Range & $\sum$ student & Percentage (\%) \\
\hline Poor & $\mathrm{x}<1.7$ & 0 & 0 \\
\hline Moderate & $1.7>\mathrm{x}<3.3$ & 3 & 9.68 \\
\hline Good & $\mathrm{x}>3.3$ & 28 & 90.32 \\
\hline & & \multicolumn{2}{|c}{$\sum=31$} \\
\hline & & \multicolumn{2}{|c}{ Mean grade score $=3.85$} \\
\hline
\end{tabular}

Journal writing scores after the learning process with the guided inquiry model was made by the experimental class students at each meeting. From the table above, it is known that there were 3 students in the medium category and 28 in the good category. Thus it can be said that the experimental class students are included in good category for writing journals in the guided inquiry learning model.

\section{Discussion}

This research was conducted in April 2019 at SMA Negeri 2 Ngaglik. The objective of this study was to find out whether there was an effect of guided inquiry models with student journals on students' critical thinking skills on environmental change subject in class X. Before conducting research, researchers first conducted a pre-study where the activities carried out were interviewing biology class $\mathrm{X}$ subject teachers regarding learning activities at school then compiling research instruments (syllabus, lesson plans, worksheets, and description questions). After that, the research instrument was validated by the expert lecturers. After being declared valid, the instruments were used in this study. 
Based on the results of this study the guided inquiry model with student journals has the effect of increasing students' critical thinking skills as evidenced by the t-test determined from the comparison of the mean posttest scores of students' critical thinking skills on environmental change subject. This can be seen from the diagram in the research results above. The diagram also explains that the value of students' critical thinking skills in the control and experimental classes had different values as evidenced by the t-test, where sig. (2tailed) posttest data was 0.000 . This shows that if $\mathrm{p}<0.05$, the value of students' critical thinking skills was significantly different.

The increase in students' critical thinking skills in the control and experimental class can be seen through the N-Gain test. From the N-Gain analysis the data for the control class was 0.44 , while for the experimental class was 0.77 . These results indicated that the increase in students' critical thinking skills in the experimental class was higher than in the control class. Research conducted by Glandys U. Jack $(2013)^{[11]}$ stated that learning with concept of mapping and guided inquiry is more effective in teaching difficult concepts and able to improve student performance and retention. In line with this opinion, in the study conducted by Evrim Ural $(2016)^{[24]}$, it is said that the guided inquiry learning model can improve student achievement, including critical thinking skills. Furthermore, research conducted by Florida F. and Mariam Abdul Rahman (2014) ${ }^{[7]}$ highlighted that using reflective journal writing can provide opportunities for students to connect theory and practice so as to enhance student learning experiences. In addition, in research by Rama Cahyati $(2018)^{[2]}$, student journals provide an increase in the ability to apply student concepts in environmental change subject. So learning using guided inquiry learning models with student journals for students will affect students' critical thinking skills and achieve learning goals.

The guided inquiry learning model with student journals used in this study departed from interviews and observations with biology subject teachers which indicated that this model has never been implemented in environmental change subject. Students only learn from textbooks and other learning resources without experimenting about problems faced in the environment. With this guided inquiry model students learn through experiments conducted with the guidance of the teacher as a facilitator, so students can investigate problems that occur with scientific expertise owned. In addition, with this model, the teacher's role leads to curiosity, encourages thinking with his own initiative, actively processes information, and avoids memorizing habits on students. [ A student's journal is a student's reflective notes made by students to find out what students have learned. Student journals that are written are expected to be able to link and connect between problems and knowledge possessed by students so that students are able to think critically in facing the facts of problems in daily life. Development of critical thinking skills can be done by exposing students to factual problems.

\section{Conclusion}

Based on the results of research, it can be concluded that the guided inquiry model with student journals has an effect on increasing students' critical thinking skills. This is based on the results of data analysis which shows significant differences between students that apply guided inquiry models with journals and students that do not apply such learning model.

\section{References}

[1] Arends, Learning to teach, (9th.ed). Connect Learn Succeed, McGrawHill 
[2] Cahyati, Rama. 2018. Efektifitas Model Guided Inquiry disertai Jurnal Peserta Didik Terhadap Kemampuan Menerapkan Konsep Perubahan Lingkungan di Kelas X SMA. Tesis. UNY.

[3] Chase, A., Pakhira, D., \& Stains, M. (2013). Implementing process-oriented, guidedinquiry learning for the first time: Adaptations and short-term impacts on students' attitude and performance. Journal of Chemical Education, 90(4), 409-416. https://doi.org/10.1021/ed300181t

[4] Conway, C. J. (2014). Effects of guided inquiry versus lecture instruction on final grade distribution in a one-semester organic and biochemistry course. Journal of Chemical Education, 91(4), 480-483. https://doi.org/10.1021/ed300137z

[5] Domin, D. S. (1999). A review of laboratory instruction styles. Journal of Chemical Education, 76(4), 543-547.

[6] Douglas, E. P., \& Chiu, C.-C. (2012). Process-oriented Guided Inquiry Learning in Engineering. Procedia - Social and Behavioral Sciences, 56(Ictlhe), 253-257. https://doi.org/10.1016/j.sbspro.2012.09.652

[7] Estrada, F. F., \& Hjh Mariam A. R. 2014. Reflective Journal Writing as an Approach to Enhancing Students Learning Experience. Brunei Derussalam Journal of Technology and Commerce, 8(1). Retrived from www.utb.edu.bn/bdjtc/BDJTC\%202014/P03.pdf

[8] Hake R R 1998 Interactive-engagement versus traditional methods: A sixthousandstudent survey of mechanics test data for introductory physics courses American Journal of Physics Research 661 64-74.

[9] Hein, S. M. (2012). Positive impacts using POGIL in organic chemistry. Journal of Chemical Education, 89(7), 860-864. https://doi.org/10.1021/ed100217v

[10] Hmelo-Silver, C. E., Duncan, R. G., \& Chinn, C. A. (2007). Scaffolding and achievement in problem-based and inquiry learning: A response to Kirschner, Sweller, and Clark (2006). Educational Psychologist, 42(2), 99-107. https://doi.org/10.1080/00461520701263368

[11] Jack, G. U. 2013. Concept Mapping and Guided Inquiry as effective techniques for Teaching Difficult Concepts in Chemistry: Effect on Students Academic Achievement. Journal of Education and Practice, 4(5).

[12] Jatmiko, B., Prahani, B. K., Munasir, Supardi, Z. A. I., Wicaksono, I., Erlina, N., ... Zainuddin. (2018). The comparison of oripa teaching model and problem based learning model effectiveness to improve critical thinking skills of pre-service physics teachers. Journal of Baltic Science Education, 17(2), 300-319.

[13] Kitot, A. K. A., Ahmad, A. R., \& Seman, A. A. (2010). The effectiveness of inquiry teaching in enhancing students' critical thinking. Procedia - Social and Behavioral Sciences, 7(C), 264-273. https://doi.org/10.1016/j.sbspro.2010.10.037

[14] Koksal, E. A., \& Berberoglu, G. (2014). The Effect of Guided-Inquiry Instruction on 6th Grade Turkish Students' Achievement, Science Process Skills, and Attitudes Toward Science. International Journal of Science Education, 36(1), 66-78. https://doi.org/10.1080/09500693.2012.721942

[15] Liliasari. (2009). Peningkatan Kualitas Guru Sains Melalui Pengembangan Keterampilan Berpikir Tingkat Tinggi. Bandung: UPI.

[16] MacKay, J. A., \& Wetzel, N. R. (2014). Exploring the wittig reaction: A collaborative guided-inquiry experiment for the organic chemistry laboratory. Journal of Chemical Education, 91(5), 722-725. https://doi.org/10.1021/ed3003836 
[17] Mundilarto. (2012). Effect of Problem-Based Learning on Improvement Physics Achievement and Critical Thinking of Senior High School Student. Journal of Baltic Science Education, 16(0), 761-779.

[18] Nariman, N., \& Chrispeels, J. (2015). PBL in the Era of Reform Standards: Challenges and Benefits Perceived by Teachers in One Elementary School. Interdisciplinary Journal of Problem-Based Learning, 10(1). https://doi.org/10.7771/1541-5015.1521

[19] Özyurt, Ö. (2015). Examining the critical thinking dispositions and the problem solving skills of computer engineering students. Eurasia Journal of Mathematics, Science and Technology Education, 11(2), 353-361. https://doi.org/10.12973/eurasia.2015.1342a

[20] Shishigu, A., Hailu, A., \& Anibo, Z. (2018). Problem-based learning and conceptual understanding of college female students in physics. Eurasia Journal of Mathematics, Science and Technology Education, 14(1), 145-154. https://doi.org/10.12973/ejmste/78035

[21] Silbermen, M.L. 2013. Active Learning 101 Cara Belajar Siswa Aktif. Bandung: Nuansa Cendikia

[22] Simanjuntak, D., Elvis Napitupulu, E., Manullang, M., Manalu, R., \& Sinambela, L. (2019). The Enhancement Difference of Student Mathematical Problem Solving Ability between Guided Discovery Learning Model and Direct Learning Model. American Journal of Educational Research, 6(12), 1688-1692. https://doi.org/10.12691/education-6-12-15

[23] Tan, O. S. (2003). Problem-based learning innovation: using problems to power learning in the 21st century. GALE Cengage Learning

[24] Ural, Evrim. 2016. The Effect Guided Inquiry Laboratory Experiments on Science Students Chemistry Laboratory Attitudes, Anxiety and Achievement. Journal of Education and Training Studies, 4(4).

[25] Wartono, W., Hudha, M. N., \& Batlolona, J. R. (2018). How are the physics critical thinking skills of the students taught by using inquiry-discovery through empirical and theorethical overview? Eurasia Journal of Mathematics, Science and Technology Education, 14(2), 691-697. https://doi.org/10.12973/ejmste/80632

[26] Wiersma W and Jurs S 2009 Research methods in education, ninth edition (USA: Pearson Education, Inc) 